the proximate composition of sound, mature, true wood from authentic samples of the timbers with the view of studying (1) their general composition; (2) the possibility of constancy of chemical factors within a species, and of regular differences between species, so that these factors might be used in the identification of the timbers; (3) the variation of chemical composition within a tree; and (4) the applicability to Australian timbers of existing standard methods of wood analysis.

Some striking differences in chemical composition have been revealed between the eucalypts examined and the hardwoods of North America for which analyses are recorded. The eucalypts may be said to be characterised by the presence in their vessels, rays, and fibres of gum-like, brittle, extraneous substances which are not soluble in the usual organic solvents, but are readily soluble in alkaline solutions. The eucalypts possess definitely lower contents of cellulose and total pentosans than North American hardwoods do, even though due consideration is made for differences in extractives. It is interesting to note that the lignin content is much the same for both series in spite of the different analytical methods used, and, if it is assumed that the apparent lignin content of the North American woods will be decreased by initial treatment with $N / 8$ sodium hydroxide, then the figures will probably be nearly the same.

The present study has revealed the fact that the standard methods for wood analysis employed in other countries are not readily applicable to the eucalypts. Here again the extraneous substances have played an important part. Their brittle nature has served to indicate that the so-called standard method of sampling wood in the form of sawdust, powder, etc., is inaccurate. Their insoluble nature and resistance to acid hydrolysis have resulted in the failure of the usual method for indicating the correct lignin content of woods. Consequently, the methods of analysis have had to be considerably modified, and it would appear that these modifications are applicable to wood analysis in general.

\title{
Developments in Highway Research
}

$\mathrm{P}$ ROF. STEINBURG of University of Maryland gave a radio talk on January I3 under the auspices of Science Service over the Columbia broadcasting system on developments in highway engineering. Of the many problems confronting the engineer, the one in which the public is most interested is that of safety in the streets. In the United States there is a rapidly increasing motor-car annual toll of about 34,000 lives and a million injuries.

Although primarily an engineering problem, highway safety is very considerably affected by the psychological, as well as the physical, demands upon the driver of a motor-vehicle. Recent research has shown that the human factor is responsible for approximately ninety per cent of motor-vehicle accidents in the United States and that the causes attributed to defects in the highway or the vehicle are of small relative importance. A psychological study was recently made at the Iowa State College of 2,000 drivers. They were tested on a specially constructed outside road as to their action and reaction when lights, signals, direction and warning signs were encountered. The results showed that the drivers could be divided into three classes. The first class consists of the 'accident free' drivers and comprises about seventy-five per cent of those tested. This group causes little trouble in any ordinary circumstances. The second group numbers about twenty per cent of the total and contains the 'accident liable' drivers who give trouble from various causes. Some are irresponsible, some are preoccupied through illness or personal affairs, while others are careless. Their failure arises either from heredity or environment and renders it necessary for the highway engineer to provide fool-proof roads. The third small group and the individuals who compose it generally suffer from some defect such as colour blindness, restricted field of vision, double vision of a single object, or extreme nervousness and poor co-ordination. Now as half the total accidents are caused by only about seven per cent of all drivers, it is obvious that special consideration has to be given to this third class.

A recent study of road signal signs shows that in the central west of the United States they are well standardised as to form, size, colour and location, while in the east there is much diversity of practice. Delaware has recently experimented with a pictographic signpost showing the direction of the roads on the marker by drawings similar to those used in Canada. They were found much clearer and more easily understood than the type in general use. Experiments have shown that arrow pointers are superior to the marks $R$ and $L$ for indicating right and left, as many people are momentarily nonplussed when told to go to the right or to the left; and it has been found that for road markers, canary yellow is much the best colour, as it stands out well from surrounding objects at all seasons of the year, and, as the human eye is very sensitive to yellow light, it is good for low illuminations.

Experiments were quoted showing that the capacity of a two-lane road is 1,000 vehicles per hour, for a three-lane road it is 2,000 and for a four-lane 3,000 vehicles and that the risk of accident is greatest with the three-lane road. This research in highway engineering has been a valuable one and has led to many practical changes which will result in a very large saving of both highway funds and vehicle operating costs.

\section{Nomenclature of British Marine Mollusca*}

$\mathrm{I}^{\mathrm{N}}$ revising the "List of British Marine Mollusca" for his presidential address to the Conchological Society, Mr. R. Winckworth has, admittedly, attempted a difficult task which is bound to bring forth criticism. A new list was certainly wanted, for it is

* "The British Marine Mollusca", by R. Winckworth. Journal of * "The British Marine Mollusca", by R. Winckworth. Journal of
Conchology, 19, No. 7, June 1932 (Presidential Address, Oct. 1931). more than thirty years since a special committee of the Conchological Society published one (J. Conchol., 10, No. 1. Jan.. 1901) which is now in many ways out of date. All workers on the group will be grateful for this well-authenticated revision, compiled by one who is an authority on the subject.

The greatest difficulty which one meets in 
deciding correct nomenclature is not now so much the weight of old literature which has to be perused in order to ascertain which authority has priority, heavy as this burden is, but the keeping up to date with new work constantly appearing which brings forward new facts necessitating alterations. Thus every day new data turn up, old names must be abandoned and new relationships admitted.

One of the obstacles to be met in making a natural classification is the absence of detailed knowledge of the life-histories of the various molluses. A thorough acquaintance with the eggs and larvæ at all stages would do away with much that is obscure. Mr. Winckworth in his preliminary remarks refers to work lately begun at the Marine Biological Laboratory, Plymouth, which is an attempt to supply this want. Already it is proving useful in determining the natural relationships of gastropods.

Another serious disadvantage is the inability of workers in general to see a large enough series of shells. Work such as has lately been published by
Mr. John Colman ("A Statistical Test of the Species Concept in Littorina". Biological Bulletin, 42. No. 3. June, 1932) is valuable.

In 1931 the Marine Biological Association pub. lished $a$ second edition of the "Plymouth Marine Fauna" in which the nomenclature of the Lamellibranchiata and to a less extent the Gastropoda were revised by Mr. Winckworth. In his new list, however, quite a number of the names (family, genus and species) have been changed; for example, Erato loevis altered to Erato voluta on account of a few months priority of Montagu over Donovan : Psammosolen candidus (Renier) altered to Solecurtus scopula (Turton) and many others. This is a good example of the difficulties encountered in undertaking such an arduous piece of work.

The "List of British Marine Mollusca" can be purchased from the Secretary of the Conchological Society of Great Britain and Ireland, Manchester Museum, The University, Manchester, or from Messrs. Dulau and Co., Ltd., 32 Old Bond Street, London, W.1, price $9 d$.

\section{The Iron and Steel Industry}

$\mathrm{T}$ $\mathrm{HE}$ last of the present series of lectures on industrial affairs at the Imperial College of Science and Technology was delivered on February 23 by Sir William Larke who took as his subject "The Iron and Steel Industry". He pointed out that although the smelting of iron ore with charcoal has been carried on since 2500 B.c. or even earlier, smelting with coal or coke was not established success. fully until 1730-35. Between 1740 and 1840 the production of pig iron in Great Britain rose from 17,350 tons to $1 \frac{1}{2}$ million tons, but it was not until about 1860 that the 'iron age' gave place to the 'steel age'. This change was signalised by the rapid development of railways and by the substitution of steel for iron in shipbuilding. As the birthplace of the iron and steel industries and of the blast furnace, the steel furnace and the rolling mill, Great Britain was for many years the leading producer, but owing to intensive developments in other countries, especially the United States and Germany, it had fallen to third place in respect of pig iron production by 1913.

After the War, the important iron ores of Lorraine came under French control, and when Germany recovered her economic freedom in 1925 the products of this district were thrown upon the world markets. In the meantime, other countries were building up iron and steel industries and Great Britain was practically the only accessible free market for the huge surplus Continental production. It is noteworthy, however, that if the world consumption of pig iron had continued to increase at the average rate of 6 per cent a year which was maintained between 1810 and 1910 , it would have reached 186 million tons in 1932: the actual production in that year was only 38 million tons and the productive eapacity 120 million tons.

Sir William Larke believes that we are suffering to-day from under-consumption rather than from over-production. The organisation of the German iron and steel industry on a national basis was followed by the formation of a Continental steel cartel, but with eontraction in demand, prices could not be maintained and fell eventually below the cost of production. The cartel ceased to function in 1930 .
The British market was the cockpit in which the price warfare was waged : after the introduction of protection Continental producers were endeavouring to maintain their sales at priees as much as 40 per cent less than the cost of production.

It might be supposed that the fall in prices of iron and stoel would react to the advantage of those industries which use these commodities as their raw materials. Under pre-War conditions, when the general demand for goods was expanding rapidly, this would have been true, but it must be realised that these conditions no longer prevail. Undertakings involving the large-scale consumption of steel, for example, shipbuilding, are actually held back lest a further fall in price should render the enterprise uneconomic at the new level. In fact the present economic situation is probably unique in the history of mankind, and the solution of its problems cannot be found on pre-War lines. In Great Britain steps have been taken and are being taken towards the establishment of a strong national organisation of the iron and steel industry. Unrestricted competition, which was formerly advantageous in promoting efficiency and stimulating enterprise, now requires to be strictly limited. Since what we call the iron and steel industries really consist of about a dozen related industries, there are many conflicting interests to be reconciled; but much has already been done in the establishment of co-operation. not only at home, but also at Ottawa with the Dominions.

The next step is international co-operation to regulate production in relation to demand and to stimulate consumption. So long as the British market was open, little could be done in this direction. The adoption of a protectionist policy has, however, brought about conditions favourable for negotiations with foreign producers, and our cooperation is now being actively sought. In fact, at the beginning of this month an agreement was signed for a new cartel, which is to deal with export trade only. This cartel will be maintained only if sales agreements can be made and a stabilisation of price lovels achieved.

In conclusion, Sir William Larke referred to the prospects for scientifically trained men in industry. 